УДК 629.4.027

\title{
ВИЗНАЧЕННЯ НАПРЯМКІВ ПІДВИЩЕННЯ НАДІЙНОСТІ ТЯГОВИХ ДВИГУНІВ ЕЛЕКТРОПОӤЗДІВ НА ОСНОВІ АНАЛІЗУ ЇХ ВІДМОВ В ЕКСПЛУАТАЦІї
}

М.С. Стариченко

\section{ОПРЕДЕЛЕНИЕ НАПРАВЛЕНИЙ ПОВЫШЕНИЯ НАДЕЖНОСТИ ТЯГОВЫХ ДВИГАТЕЛЕЙ ЭЛЕКТРОПОЕЗДОВ НА ОСНОВЕ АНАЛИЗА ИХ ОТКАЗОВ В ЭКСПЛУАТАЦИИ}

М.С. Стариченко

\section{DETERMINE WAYS TO IMPROVE RELIABILITY OF ELECTRIC TRACTION MOTORS ON THE BASIS OF THEIR FAILURE TO OPERATE}

\section{M.S. Starichenko}

У статті розглянуто умови роботи тягових двигунів електропоїзів ЕР2Т моторвагонного депо Ясинувата. Проведено короткий аналіз надійності тягових двигунів 8 експлуатації. Визначені основні способи підвищення експлуатаційної надійності тягових двигунів електропоїздів.

Ключові слова: тяговий двигун, надійність, відмова, пошкодження, експлуатачія, аналіз, електропоїз.

В статье рассмотрены условия работы тяговых двигателей электропоездов ЭР2Т моторвагонного депо Ясиноватая. Проведен краткий анализ надежности тяговых двигателей в эксплуатации. Определены основные способы повымения эксплуатационной надежности тяговых двигателей электропоездов.

Ключевые слова: тяговый двигатель, надежность, отказ, повреждение, эксплуатация, анализ, электропоезд.

In the article the terms of the traction motors of electric railcar depot ER2T Yasinovataya. The brief analysis of the reliability of the traction motors to operate. The main ways to increase the operational reliability of the traction motors.

Keywords: traction motors, reliability, failure, injury, operation, analysis, electric train.

Постановка проблеми. Складна економічна ситуація в країні та залізничній галузі, старіння локомотивного парку висуває на перший план питання більш повного використання всіх видів ресурсів. Вона змушує розробляти заходи щодо підвищення ефективності експлуатації рухомого складу залізниць. Відомо, що одним з основних факторів, які визначають ефективну роботу тягового рухомого складу, є його надійність. Одними з вузлів, що обумовлюють надійність тягового рухомого складу, $\epsilon$ тягові електричні двигуни. Наслідки відмов тягових двигунів в експлуатації приводять до значних матеріальних збитків.

Аналіз досліджень i публікацій. Проблеми дослідження надійності тягових двигунів електрорухомого складу постійно знаходяться в полі зору вчених та практиків $[1,2]$. На основі натурних спостережень робилися висновки про вплив тих чи інших 
факторів на виникнення відмов та пошкоджень, на основі теоретичних розробок будувалися моделі явища. У той же час, зусилля багатьох авторів, спрямованих на вирішення окремих питань цього явища, не завжди призводять до очікуваного результату. Успіху можна досягти тільки при комплексному підході до вирішення проблеми. Крім того, на надійність тягових двигунів локомотивів впливає також ступінь вичерпаності ресурсу, відмінність умов експлуатації на різних залізницях та депо, різна вантажонапруженість окремих ділянок вимагає індивідуального підходу в кожному конкретному випадку. Це доводить необхідність прийняття рішень щодо впровадження заходів 3 підвищення надійності електричних двигунів тільки після детального аналізу місцевих умов експлуатації, технічного стану парку рухомого складу, технологічних можливостей ремонтного виробництва.

Мета статті. Визначити основні напрямки підвищення надійності тягових двигунів електропоїздів серії ЕР2Т, виходячи 3 місцевих умов їх роботи на плечах обслуговування моторвагонного депо Ясинувата та аналізу відмов.

Виклад матеріалу. Високий рівень промислового розвитку району тяжіння Донецької залізниці, значна населеність регіону зумовили високу вантажо- та пасажиронапруженість ii основних напрямків, яка в 5-6 разів вища за середню по Укрзалізниці. Електропоїзди моторвагонного депо працюють в приміському пасажирському русі на ділянках Ясинувата Маріуполь; Ясинувата - Чаплине, Ясинувата -Слов'янськ - Красний Лиман, Донецьк - Дебальцеве - Луганськ; Ясинувата - Антрацит, Ясинувата Іловайськ. Парк моторвагонного депо Ясинувата складається 3 електропоїздів постійного струму різних серій: ЕД2Т - 10 електро-поїздів, ЕПЛ2Т - 9 електропоїздів, ЕР2Т - 21 електропоїзд.

Останніми роками, в при незначному зниженні загального пробігу електропоїзд- дів, майже вдвічі збільшився деповський відсоток несправних, що вказує на значне погіршення технічного стану електропоїздів.

Збір даних щодо відмов тягових двигунів в експлуатації проводився 3 використанням даних облікових журналів ф. ТУ-29 та ТУ-152 за останні три роки. Статистичні дані оброблялись за допомогою методів математичної статистики, а отримані результати наводились в графічному вигляді. 3 поданої гістограми розподілу відмов тягових двигунів по пробігу (рис. 1) видно, що пік 25 \% відмов виникає при пробігах до 121 тис. км. Після незначного зменшення кількості відмов, при пробігах до 200 тис. км, починається повторне зростання. Пробіг електропоїзда для проведення ремонту ПР-3 становить 350 тис. км, і на нього припадає 78\% всіх відмов. В перерахунку на кількість це становить 25 відмов. 3 отриманих результатів можна зазначити, що в даних умовах, при досягненні пробігів більше 100 тис. км, тягові двигуни потребують більшої уваги при експлуатації та технічних обслуговуваннях. Тобто особливу увагу необхідно приділяти контрольним операціям при проведенні ПР-1.

Для визначення впливу сезонних чинників на надійність тягових двигунів будувалась відповідна гістограма розподілу їх відмов (рис. 2), 3 якої видно, що найбільше відмов та пошкоджень відбувається в міжсезоння.

Це пов'язано з тим, що в міжсезонний період значно підвищується вологість повітря, це негативно впливає на стан ізоляції електричних машин. Дані гістограми вказують також на незмінність потоку відмов у зимовий період та частину весняно-літнього періоду, що потребує додаткового вивчення на предмет відповідності таким гіпотезам:

- недосконала система реєстрації відмов та пошкоджень обладнання тягового рухомого складу (помилки персоналу при заповненні облікових форм); 


\section{Рухомий склад та спеціальна техніка залізничного транспорту. Локомотиви}

- особливості зовнішніх кліматичних умов конкретного сезону;
- недостатня кількість статистичного матеріалу.

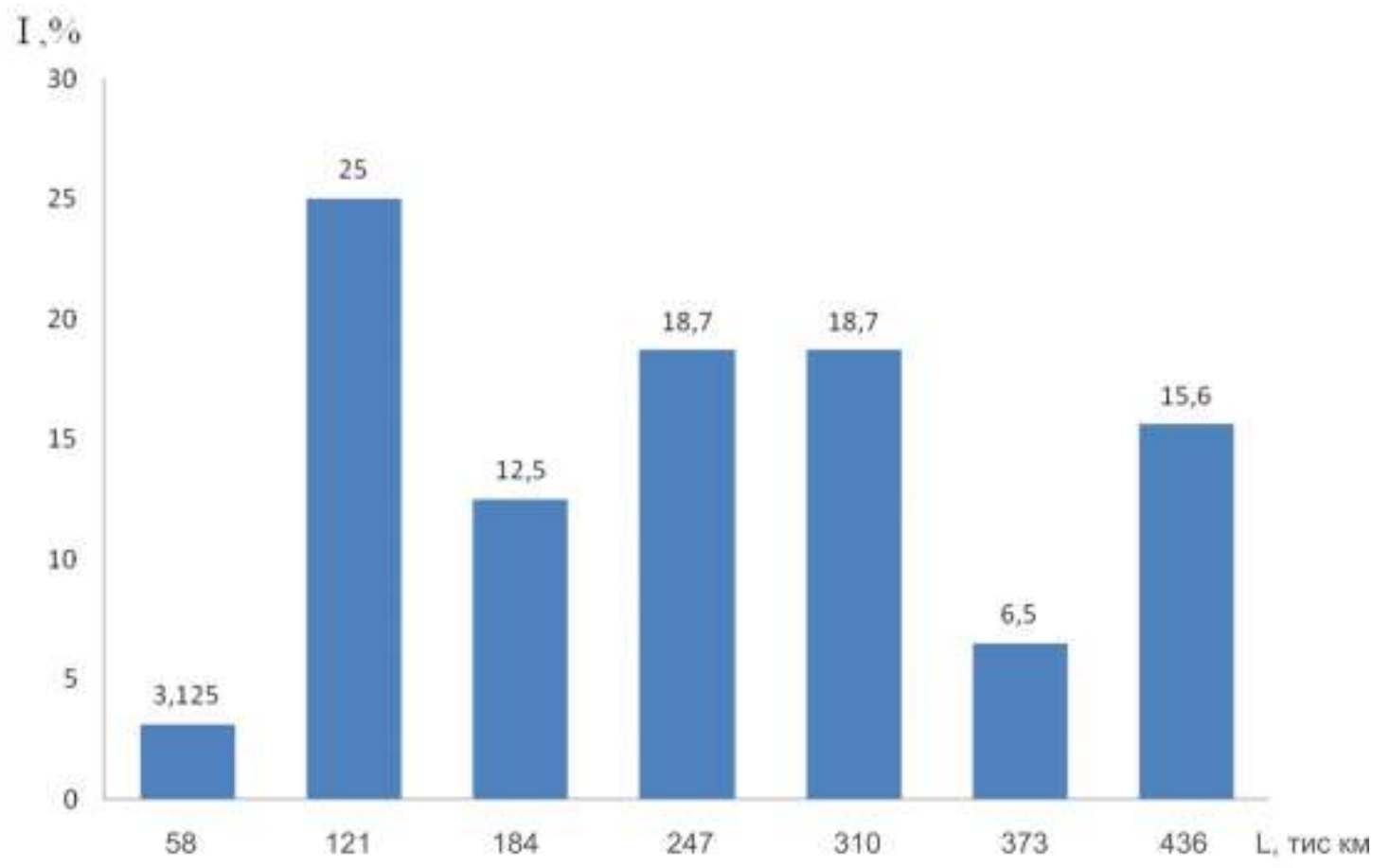

Рис. 1. Гістограма розподілу відмов тягових двигунів електропоїздів по пробігу

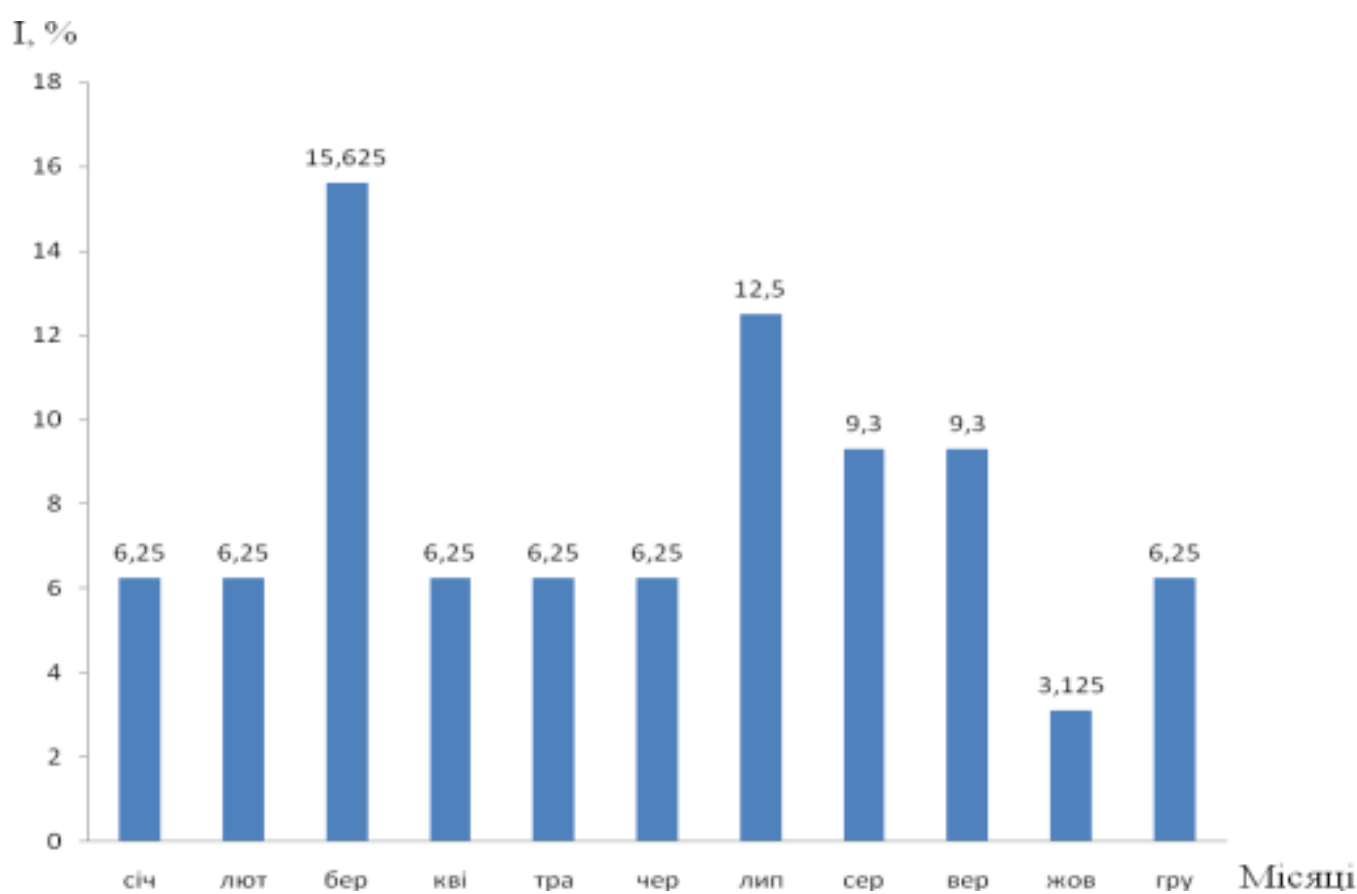

Рис. 2. Гістограма розподілу відмов тягових двигунів електропоїздів за сезонами експлуатації 
Незважаючи на наявність можливої похибки, можна зазначити періоди міжсезоння як найбільш напружені щодо відмов тягових двигунів. Для виявлення найменш надійних вузлів та деталей тягових двигунів будувалась гістограма розподілу відмов за характером виникнення (рис. 3), 3 якої видно, що майже по $22 \%$ відмов припадає на пошкодження ізоляції та замикання обмоток якоря (A) та збудження (D). Високий відсоток відмов припадає на пошкодження бандажів якорів (B) та зниження опору ізоляції (C). Значно менше випадків відмов $(6,25 \%)$ припадає на пошкодження щіткотримачів (F) та колектора $(\mathrm{G})$. Найменша кількість відмов припадає на пошкодження міжкотушкових з'єднань (Н), підшипникових вузлів (К) та кріплення полюсів (I).

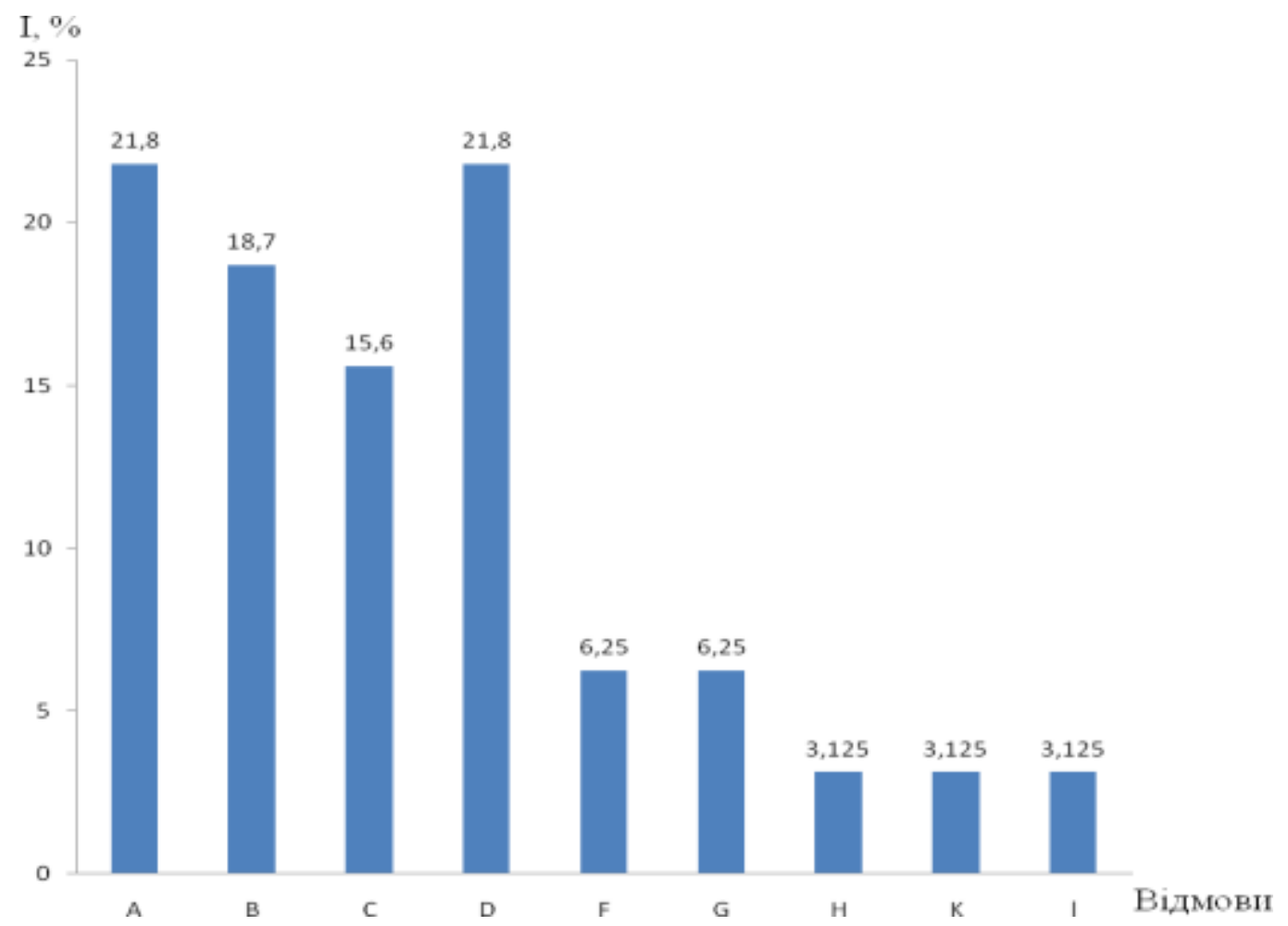

Рис. 3. Гістограма розподілу відмов тягових двигунів електропоїздів за характером виникнення

Проведений аналіз вказує на недостатню надійність тягових двигунів електропоїздів, що дозволяє сформувати основні шляхи іiі підвищення в експлуатації:

- удосконалення технології контрольних операцій по тягових двигунах при проведенні ПР-1 електропоїздів;

- впровадження сучасного діагностичного обладнання 3 контролю ізоляції та струмоведучих частин тягових двигунів;
- підвищення уваги до якості контрольних та профілактичних операцій по тягових двигунах в періоди міжсезоння та за умов збільшення вологості повітря.

Висновки. В результаті проведених робіт було визначено, що тягові двигуни електропоїздів ЕР2Т моторвагонного депо Ясинувата характеризуються низькою надійністю в експлуатації. На основі аналізу параметрів відмов та пошкоджень тягових двигунів сформульовані основні напрямки підвищення їх експлуатаційної надійності. 


\section{Список використаних джерел}

1. Исаев, И.П., От чего зависит ресурс тяговых двигателей [Текст] / И.П. Исаев, А.В. Горский, С.М. Хлопков // Электрическая и тепловозная тяга. - 1982. - №6. - С. 36-39.

2. Постников, Р.А. Влияние условий эксплуатации на надежность оборудования электроподвижного состава [Текст]: дис... канд. техн. наук: 05.22.07 / Р.А. Постников. - М., 2005. $-158 \mathrm{c}$.

Рецензент д-р техн. наук, професор В.Г. Пузир

Стариченко М.С., слухач ІППК гр. МЗ-Л-Б-11, моторвагонне депо Ясинувата.

Starichenko M.S. 